Veljko Bisić

\title{
Rezime
}

Tekst sažeto sublimira dosadašnji normativni okvir u kojem se razvijala komplajans funkcija, uticaj međunarodnih standarda u pogledu prakse koja se razvija, kao i predlog mogućeg redefinisanja propisa sa ciljem efikasnog minimiziranja komplajans rizika i odgovarajućeg organizacionog i kadrovskog postavljanja funkcije.

Ključne reči: komplajans, kontrola usklađenosti poslovanja (KUP), funkcija, organizaciona jedinica 


\section{COMPLIANCE, WHERE DO WE GO NEXT?}

Veljko Bisić

Addiko Bank a.d. Belgrade veljko.bisic@addiko.com
Translation
provided by
the author

\section{Summary}

The text summarizes the current normative framework in which the compliance functions developed, the impact of international standards on the developing practice, and a proposal for the possible redefinition of regulations with the aim of effectively minimizing the compliance risk and achieving the appropriate organizational and personnel positioning.

Keywords: compliance, control, function, organization unit

JEL: G21, M14 
$\mathrm{P}$ rošlo je nešto više od deset godina od kako su organizacija i nadležnosti funkcije kontrole usklađenosti poslovanja (eng. compliance) utvrđeni propisima i uvedeni $\mathrm{u}$ specifičnu kontrolnu praksu poslovanja banaka. U pitanju je značajan period koji dozvoljava retrospektivne analize toga dokle se došlo u razvoju funkcije i koji su mogući dalji pravci njenog unapređenja. Da li se odavno okončao inicijalni period razumevanja polja rada i ciljeva ove funkcije, kada se on, uglavnom, izjednačavao ili poistovećivao sa implementacijom propisa u oblasti sprečavanja pranja novca i finansiranja terorizma? Ili je komplajans i danas, prema projekciji mnogih, bunar lepih želja koji ima odgovor na sva pitanja, tj. drugi naziv za ono što radi sektor pravnih poslova ili odličan paravan za delegiranje vlastite odgovornosti u razumevanju i primeni propisa?

Funkcija kontrole usklađenosti poslovanja (dalje: KUP), utemeljena je po prvi put Zakonom o bankama (Sl. glasnik RS 107/2005 - dalje u tekstu: Zakon) kojim su propisani sledeći najvažniji postulati:

- delokrug poslova kontrole usklađenosti poslovanja obavlja posebna organizaciona jedinica,

- organizaciona jedinica je nezavisna u svom radu, što potvrdu dobija i činjenicom da rukovodioca jedinice imenuje i razrešava upravni odbor banke,

- jasna su kontrolna ovlašćenja, budući da je zaposlenima u organizacionoj jedinici na raspolaganju pravo uvida u dokumentaciju kojom raspolažu drugi zaposleni, kao i mogućnost pribavljanja potrebnih informacija od drugih zaposlenih.

Odluka o načinu i uslovima identifikacije $i$ praćenja rizika usklađenosti poslovanja banke i upravljanja tim rizikom (Sl. glasnik RS broj
86/2007 i 89/2007 - ispr. - dalje u tekstu: Odluka) predstavlja podzakonski akt koji je na snazi i efektivnoj primeni od 1. oktobra 2007. godine. Reklo bi se, prema dužini proteklog perioda od kako je Odluka na snazi i izostanku njenih izmena i dopuna, da je u pitanju akt koji je na kvalitetan i nesporan način regulisao značajnu kontrolnu aktivnost $\mathrm{u}$ radu finansijskih institucija. Međutim, postavlja se pitanje da li $\mathrm{su}, \mathrm{u}$ međuvremenu, sazrele okolnosti koje bi trebalo da preispitaju normativne temelje na kojima je sazdana funkcija KUP? Šta predstavlja predmet pažnje organizacione jedinice za KUP i kojim resursima ova jedinica raspolaže za realizaciju propisanih obaveza?

Zakonom se načelno rizik usklađenosti poslovanja banke segmentira na rizik od sankcija regulatornih tela, finansijskih gubitaka i reputacioni rizik. Ova široka postavka rizika se dosledno razrađuje Odlukom, pri definisanju obuhvata nadležnosti KUP, formulacijom da rizik usklađenosti poslovanja banke nastaje kao posledica propuštanja usklađivanja poslovanja sa zakonom i drugim propisom, standardima poslovanja, procedurama o sprečavanju pranja novca i finansiranja terorizma, kao i sa drugim aktima kojima se uređuje poslovanje banaka. Kako shvatiti ovako široko postavljen izvor rizika, osim da je na organizacionoj jedinici za kontrolu usklađenosti poslovanja prilično breme i ozbiljan zadatak identifikacije i praćenja rizika koji izviru iz obaveza raznolikih propisa koji uređuju poslovanje banaka. Dovoljno je prepoznati sav značaj obaveza i rizika povezanih sa procedurama o sprečavanju pranjanovca, kojese posebnonaglašavaju kaooblast opservacije, te uvideti svu složenost potencijalnih zahteva funkcije kontrole usklađenosti poslovanja proisteklih iz kompleksnog propisa kakav je Zakon o sprečavanju pranja novca i finansiranja terorizma.

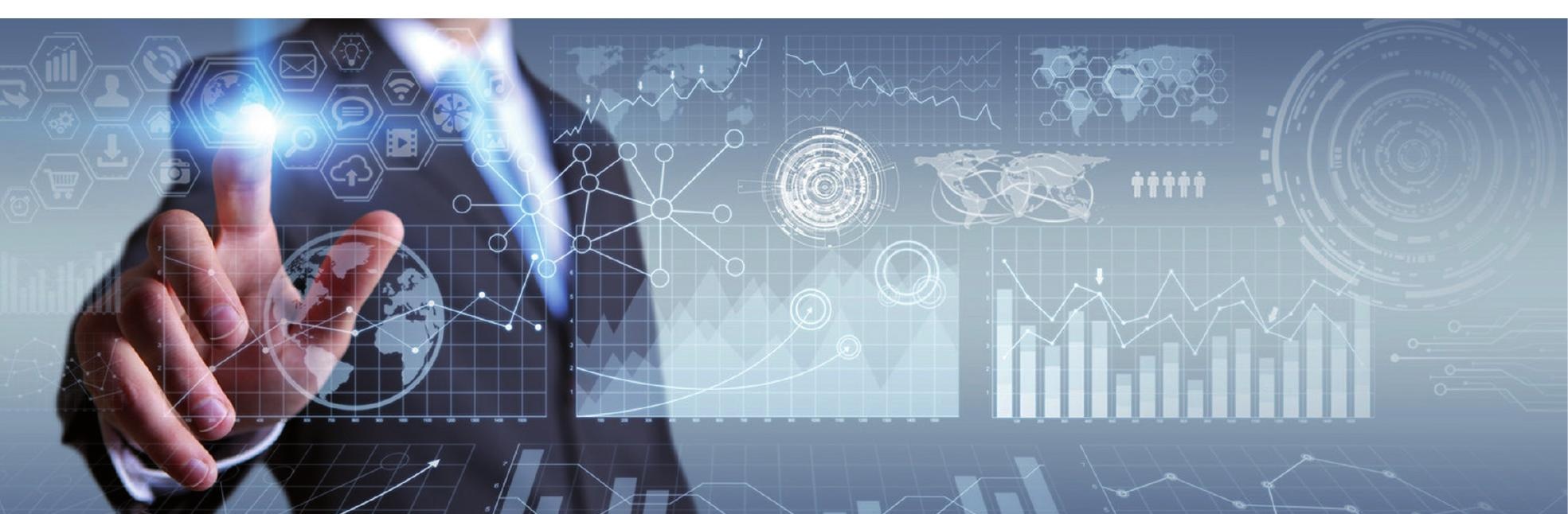


$\mathrm{I}$ t has been a little over ten years since the organization and competences of the compliance control function have been established and introduced into the specific control practice of banking operations. This is a sizeable period of time which allows retrospective analyses regarding the extent to which the function has been developed and the possible steps to be taken with the purpose of its further improvement. Did the initial period in which the field of operations and the objectives of this function were understood end a long time ago - when it was principally equated to or identified with the implementation of regulations in the area of money laundering and the financing of terrorism? Or is compliance nowadays, according to many forecasts, still a wishing well that contains the answer to all the questions, i.e. another name for what the legal department does or a brilliant screen for delegating personal responsibility in terms of understanding and applying regulations.

The compliance control function was established, for the first time, by the Law on Banks (Official Gazette of the Republic of Serbia 107/2005 - hereinafter: the Law) prescribing the following most important postulates:

- The range of compliance control activities is performed by a specific organizational unit,

- The organizational unit carries out its operations independently which is upheld by the fact that the manager of the unit is appointed and relieved of his/her duty by the board of directors of the bank,

- The control competences are clear since the employees in the organizational unit have the right to access documents used by other employees as well as the possibility to obtain necessary information from other employees.

The Decision on the Manner and Conditions of Identification, Monitoring and Management of Bank Compliance Risk (Official Gazette of the Republic of Serbia, no. 86/2007, correction $89 / 2007$ - hereinafter: the Decision) is a by-law which has been in effect and has effectively been applied as of 1 October 2007. It appears, judging from the length of the period during which the Decision has been in effect and the absence of changes and amendments to it, that it is a bylaw that has regulated controlling activities in the operations of financial institutions in an excellent and indisputable manner. However, one may pose the question whether, in the meantime, the circumstances have evolved that are meant to reassess the normative foundations upon which compliance control has been built. What should be the focus of the compliance control organizational unit and which resources does this unit have at its disposal in order to implement the prescribed obligations?

The Law initially segments the bank compliance risk into risks pertaining to regulatory body sanctions, financial loss and reputational risk. This broadly defined risk is consistently elaborated on by the Decision and its definition comprises the compliance control competences through the formulation that the bank compliance risk occurs as a result of a failure of business operations to comply with the law and other regulations, operational standards, procedures pertaining to money laundering and the financing of terrorism, as well as with other by-laws regulating banking operations. How is such a broadly defined source of risk to be understood, other than that the organizational unit performing compliance control carries quite a burden and has a serious task of identifying and monitoring risks that arise from the various obligations regulating banking operations. It is sufficient to recognize the significance of all the obligations and risks concerning the procedures pertaining to the prevention of money laundering, which are particularly emphasized as areas to be observed, as well as the entire complexity of the potential requirements of the compliance control function derived from complex regulations, as is the Law on the Prevention of Money Laundering and Financing of Terrorism.

What about other regulations which carry a risk in terms of regulatory body sanctions, or of compliance control that is under threat of financial loss, particularly business activities which may potentially or actually damage the business reputation of a financial institution or the clients' trust (reputational risk)? Are the regulations which represent a platform for performing the compliance control function the normative that regulates the rights of the financial services users or that regulates the terms and method of providing 
Šta je sa drugim propisima koji nose rizik od sankcija regulatornih tela, odnosno kontrolom usklađenosti poslovanja koje je pod pretnjom finansijskih gubitaka, a naročito postupanjem $\mathrm{u}$ poslovanju koje potencijalno ili stvarno narušava poslovni ugled finansijske institucije i poverenje klijenata (reputacioni rizik)? Da li su normativa kojom se uređuju prava korisnika finansijskih usluga ili kojom se uređuju uslovi i način pružanja platnih usluga, propisi koji predstavljaju platformu za delovanje funkcije kontrole usklađenosti poslovanja? Kako posmatrati uslove koji uređuju prikupljanje i obradu podataka o ličnosti, odnosno prava lica i zaštitu prava lica čiji se podaci prikupljaju i obrađuju, u kontekstu kontrole rizika usklađenosti poslovanja?

Praksa organizacione jedinice za kontrolu usklađenosti poslovanja jasno potvrđuje involviranost $u$ identifikaciju, procenu $i$ umanjivanje rizika proisteklih iz navedenih oblasti. Vredan doprinos za određivanje kriterijuma za nadležnost funkcije kontrole usklađenosti poslovanja otelotvoren je $\mathrm{u}$ preporukama radne grupe za komplajans pri Udruženju banaka Srbije, iz ranog perioda razvoja ove funkcije.

Kao izraz nastojanja da se zakonske i podzakonske odredbe o KUP, prevedu na operativan model rada, ponuđen je koncept koji definiše KUP kao organizacionu jedinicu koja prati usklađenost internih akata, a naročito onih koji se odnose na:

- radnje i mere u oblasti sprečavanja pranja novca i finansiranja terorizma,

- zaštitu klijenata (misli se na prava korisnika finansijskih usluga, koja su vremenom dobila svoje zakonsko utemeljenje),

- poštovanje bankarske tajne,

- konflikt interesa (misli se na pravila upravljanja kod procene postojanja konflikta interesa),

- kodeks ponašanja unutar banke,

- kodeks ponašanja u prodaji, trgovini i marketingu bankarskih usluga (proizvoda),

- pravila vezana za razvoj/izmenu postojećih i odobravanje novih usluga (proizvoda) banke,

- zloupotrebu tržišta i privilegovanih informacija koje proističu iz posebnih ovlašćenja.
Dakle, kada je reč o sadržaju preporučenih pravaca aktivnosti primetno je nastojanje nekadašnje radne grupe za KUP da postojeći, široko definisani normativni okvir, približi i pomiri sa izvorima rizika koji su prepoznati iz poslovne sfere. Ukoliko se pažnja sa domaćeg normativnog okvira, bitnog za definisanje polja nadležnosti komplajansa, usmeri na izvore koji predstavljaju međunarodni standard u razvoju komplajansa, značajnog sa stanovišta obavezne primene kod domaćih banaka - članica grupa čije su centraleu inostranstvu, prepoznaje se donekle drugačiji pristup u odabiranju prioriteta. Tako su, prema FSGO (Federal Sentencing Guidelines for Organizations - Effective Compliance and Ethics Program) ključna načela za efektivni program usklađenosti i etike sledeća: 1 . uspostavljanje takve organizacije koja će sa dužnom pažnjom sprečavati i otkrivati kriminalno ponašanje, odnosno 2. uspostavljanje organizacije koja će promovisati kulturu koja podstiče etičko ponašanje i poštovanje zakona.

Navedena načela se razrađuju kroz sledeće elemente komplajans matrice:

- uspostavljanje politika i standarda poslovnog i etičkog ponašanja,

- uspostavljanje verifikacije i nadzora, te kontunuiranog/periodičnog testiranja i kontrole radi otkrivanja kriminalnog ponašanja,

- promovisanje kulture "ton na vrhu" (Tone at the Top), kao izraz uspostavljanja najviših etičkih standarda u vrhu organizacije s ciljem prevencije prevara i druge neetičke prakse,

- promovisanje otvorene linije komunikacije za poverljive informacije, uključujući i anonimne, $\mathrm{u}$ pogledu pitanja usklađenosti, bez straha od posledica,

- pravovremeni i konzistentan odgovor na "loše" ponašanje, uz odgovarajuće disciplinske mere,

- realizacija obuke (sa pažnjom na uloge, rizike i vrednosti jasno proizašle iz obuke).

Fokus je, dakle, prvenstveno na promovisanju integriteta i etičnosti, kao i instrumenata uzbunjivanja (whistleblowing), kao snažnog podsticaja za prevenciju kriminalnog, odnosno takozvanog prevarnog ponašanja bilo zaposlenih u entitetu bilo trećih lica. Uzimajući u obzir raznolikost svih mogućih, zakonom definisanih oblasti, koje bi mogle biti izvor 
payment services? How should we address the terms regulating personal data collection and processing or the rights of persons and the protection of the rights of persons whose personal data are collected and processed in the context of compliance risk control?

The practice of the organizational unit for compliance control clearly confirms the involvement in the identification, assessment and reduction of risks arising from the above mentioned areas. The recommendations of the working group for compliance within the Association of Serbian Banks have provided a valuable contribution in determining the criteria for compliance function competences, in the early stages of this function's development.

As a demonstration of the attempt to adapt the law and by-laws regulating compliance control to an operational working model, a concept that defines compliance as an organizational unit which complies with internal by-laws has been offered, especially those referring to the following:

- Actions and measures in the area of preventing money laundering and the financing of terrorism,

- Client protection (in terms of the rights of financial services users which have been legally grounded over time),

- Respecting banking secrecy,

- Conflict of interest (in terms of the management rules in the assessment of the existence of conflict interest),

- Code of conduct within a bank,

- Code of conduct in the selling, trading and marketing of banking services (products),

- Rules pertaining to the development of/ changes in the existing banking services (products) and the authorization of new ones,

- Misuse of the market and privileged information arising from special authorizations.

Thus, when it comes to the content of recommended directions of activities, the former working group for compliance invested an evident effort to bring the existing, broadly defined normative framework closer to the recognized sources of business risk. If the focus from the local normative framework that is relevant for defining the competence of the compliance field is placed on the sources that represent the international standard in compliance development and that are significant from the point of view of their obligatory application in local banks-group members whose headquarters are located abroad, a somewhat different approach in selecting the priorities can be identified. Thus, according to the FSGO (Federal Sentencing Guidelines for Organizations Effective Compliance and Ethics Program), the key principles for effective compliance and ethics program are the following: 1. establishing the type of organization that will use due diligence prevent and detect criminal conduct, and 2. establishing the type of organization which will promote the culture that encourages ethical conduct and rule of law.

The above mentioned principles are being developed through the following elements of the compliance matrix:

- Establishing policies and standards of business and ethical conduct,

- Establishing verification and supervision and continuous/periodic testing and control for uncovering criminal conduct,

- Promoting the "Tone at the Top" culture, as a demonstration of the highest ethical standards at the top of the organization with the aim of preventing fraud and other unethical practices,

- Promoting an open line of communication for confidential information, including that which is anonymous, in respect of compliance issues, without fear of consequences,

- A timely and consistent response to "poor" conduct, with appropriate disciplinary measures,

- Implementing training programs (focusing on roles, risks and values arising from the training).

The focus is, thus, primarily on promoting integrity and ethics, as well as whistleblowing, as a powerful impetus for the prevention of criminal, i.e. fraudulent behavior of either inhouse employees or third persons. Taking into consideration the diversity of all possible areas defined by the law which could be a source of risk within the competences pertaining to identification and monitoring by the compliance control function, when the regulator takes a 
rizika u nadležnosti identifikacije i praćenja funkcije za kontrolu usklađenosti poslovanja, pri eventualnom novom normativnom sagledavanju funkcije KUP od strane regulatora, značajno bi bilo:

- razmotriti međunarodne standarde i poziciju komplajans funkcije u pogledu promovisanja postulata integriteta i etičnosti, odnosno proisteklih obaveza u vezi sa ovim,

- propisati okvir, relevantnost različitih kriterijuma, kao i dinamiku za procenu komplajans rizika, sa ciljem utvrđivanja nivoa rizika finansijske institucije, te obaveznosti i prioriteta kontrolnih aktivnosti shodno izvršenoj analizi rizika.

Jasno definisan obim odgovornosti funkcije KUP, odnosno rizika koji prate poslovanje banaka, a čiji bi uticaj ova funkcija trebalo da minimizuje, preduslov je da se ona $\mathrm{i}$ organizaciono i kadrovski valjano postavi. Tada bi i bankama bilo jednostavnije da utvrde odgovarajući obim resursa koje moraju usmeriti u ovu funkciju kako bi ona efikasno obavljala svoje zadatke. Istovremeno, to bi i regulatoru omogućilo da jasnije sagleda adekvatnost opremljenosti organizacione jedinice za KUP u odnosu na odgovornosti koje su propisane. 
potential new normative view of the compliance control function, the following factors should be of significance:

- Consider the international standards and position of the compliance function in terms of promoting integrity and ethics, or the obligations arising from this,

- Prescribe the framework, different relevant criteria, as well as the dynamics pertaining to compliance risk assessment with the aim of determining the risk level of the financial institution, as well as the obligations and priorities pertaining to control activities in accordance with the risk analysis conducted.
A clearly defined range of responsibilities of the compliance control function, or the risks that accompany banking operations, the influence of which this function is meant to minimize, is a prerequisite for it to be set up properly, both in the organizational sense and in terms of staff. Thus, it would also be easier for banks to determine the appropriate range of resources that must be directed towards this function so that it can effectively perform its tasks. At the same time, this would enable the regulator to perceive more clearly the adequacy of equipping the organizational unit for compliance control in relation to the prescribed duties. 